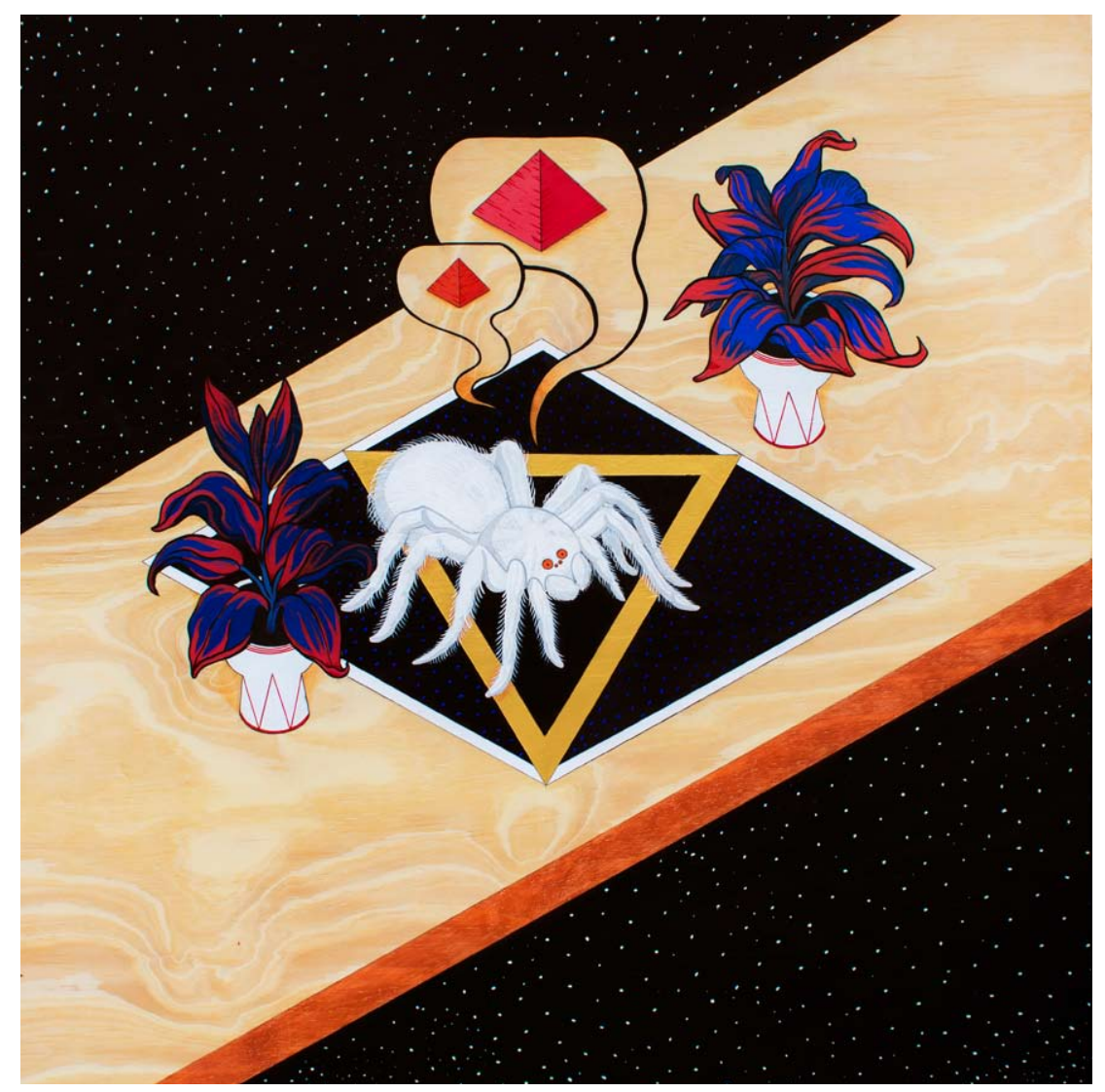

“Araña albina”, acrílico. Ramiro Achiary 


\title{
Resignificar los sentidos de la educación
}

\author{
Maria Graciela DI FRANCO
}

1 rgentina celebra en estos días los 100 años de la Reforma Universitaria, una revolución coordinada por la lucha estudiantil que se constituyó en una reivindicación académica -tanto en el terreno de la ciencia como de las ideas pedagógicas- $y$ dio lugar a una profunda renovación latinoamericana.

En el inicio del siglo XX estudiantes de la universidad de Córdoba alzaron sus voces contra una organización institucional jerárquica clerical, conservadora y arbitraria. Portaban un mandato de cambios hacia una educación democrática así como de un compromiso irrenunciable con la sociedad de la que formaban parte. La lucha logró sumar a estudiantes universitarios del resto del país y de la Federación Obrera de Córdoba, alianza que los mantuvo vinculados en distintos momentos del siglo.

El 21 de junio de 1918 se dio a conocer el Manifiesto Liminar que sintetizaba la urgencia de una universidad pública, gratita, laica, cogobernada, con concursos públicos, periodicidad en el ejercicio de docencia, autónoma, comprometida con la nación. En los años siguientes los principios fueron sostenidos por los estudiantes de Chile, Perú, Cuba, México, Paraguay y Brasil. Ese manifiesto expresa un "nosotros" que disputa un poder simbólico a favor de la rebeldía de los estudiantes en esta "hora americana" donde "la juventud ya no pide, exige".

Hoy otro manifiesto vuelve a convocarnos por la educación, la libertad, la investigación educativa, el contexto socio político en el que estamos involucrados Un manifiesto por la
Educación publicado en 2010 por Gert Biesta y Carl Anders Säfström y, cuya lectura nos permite reflexionar y manifestar(nos) sobre los sentidos de la educación a casi diez años de su publicación.

Para inaugurar el manifiesto, los autores proponen hablar en nombre de la educación reconociendo ataques originados en direcciones populistas e idealistas, pero corriéndose de esas miradas. Hablar en nombre de la educación expresa un interés en la libertad del otro. En el mismo documento se ubica a la educación en una tensión entre "lo que es" y "lo que no es". En esta tensión irrumpe un presentedisenso- que produce subjetividad y que requiere considerar a la educación fundamentalmente como histórica y abierta a lo nuevo. Esta tensión ayuda plantear interrogantes respecto a las formas de teorizar a la educación de manera educativa.

“...el manifiesto apunta a identificar los desafíos que deben afrontarse si deseamos luchar por la educación -lo cual también significa luchar por la posibilidad de la libertad"

Se pregunta Griesa “ ¿Un manifiesto por la Educación?” y reconoce que al igual que en el arte o la política que han dominado en este género, ninguno ha logrado cambiar al mundo. Por ello expresa: "En nuestros tiempos un manifiesto puede realizarse sólo de manera irónica”, es decir, para crear una apertura; para hablar en nombre de la educación; para discutir desde allí los ataques teóricos y políticos; para construir 
una teoría de la educación que tome prestado de otras disciplinas académicas; para preguntarse si tales recursos teóricos pueden capturar la dimensión educativa de la educación.

Carl Anders Säfström realiza una breve introducción histórica a fin de proveer un contexto a la educación en Suecia y el sentido fundamental que la educación reside en la base del estado de bienestar moderno, un estado 'social demócrata'. Los ataques de la nueva derecha a este estado implican ataques a la educación y a la investigación educativa. En relación a esta última, queda dependiendo de las políticas públicas de turno y es fácilmente reducida a la aplicación de ideas provenientes de la política o de otras disciplinas (didácticas específicas sociología educativa, psicología educativa, entre otras). Esa no es la educación que queremos ¡Es hora de luchar por la educación!

Este dossier que presentamos hoy es coordinado por los Doctores Luis Porta (UNMDP-CONICET-GIEEC) y Silvia Grinberg (CONICETUNSAM-CEDESI) analizando manifestaciones polifónicas de la pedagogía a partir de los once ejercicios de resistencia a favor de la educación que se publican. Un esfuerzo singular que pone en juego una intencionalidad ética y política y desde allí habitar un mundo que nos compromete por una vida mejor, más solidaria, más libre, más respetuosa.

Esto constituye un volumen especial, en tanto se organiza como un dossier centrado en las reflexiones generadas a partir del Manifiesto, lo es también en tanto todos los artículos y reseñas se publican en español e inglés y con una mayor cantidad de colaboraciones para esta temática (europeas, latinoamericanas y argentinas).

Como dicen Gert Biesta y Carl Anders Säfström no hay en el manifiesto una invitación a adherir sino a comenzar a hablar en nombre de la educación, a multiplicar y no copiar. Un territorio para reunir fuerzas, aventurar el pensamiento, revisitar la escuela, lo común, la investigación y desde allí resistir al volver a pensar los sentidos de la educación.

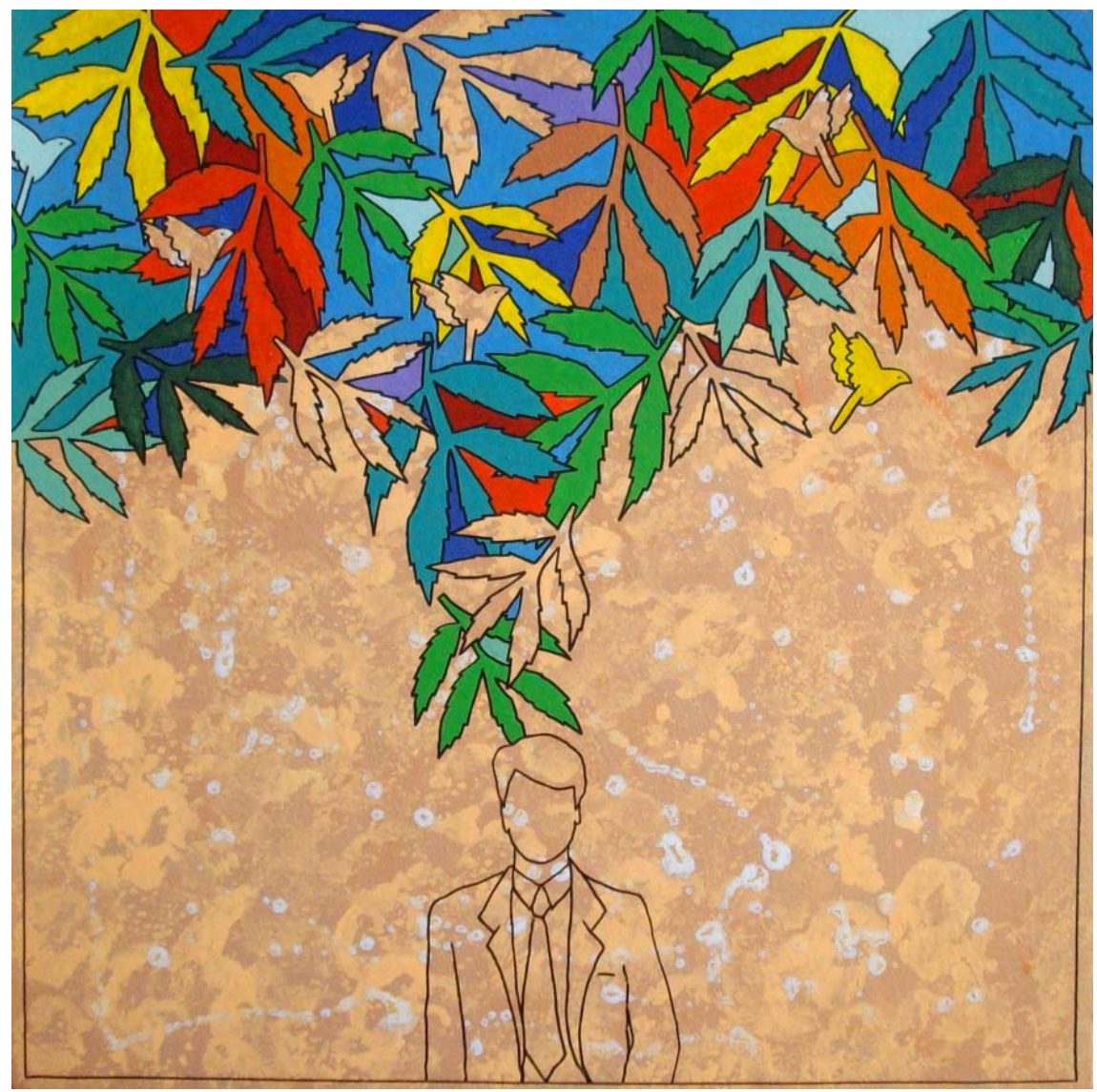

Serie indiferentes, técnica mixta. Luis Abraham 


\title{
Revising the meanings of education
}

\author{
Maria Graciela DI FRANCO
}

A rgentina celebrates these days the $100^{\text {th }}$ anniversary of the University Reform, a revolution coordinated by students' struggle that became an academic demand -both in the field of science and pedagogical ideas. Something that and gave place to a profound Latin American renewal.

At the beginning of the 20th century, students from the University of Córdoba raised their voices against a hierarchical, clerical, conservative, arbitrary institutional organization. They carried a mandate of changes towards a democratic education as well as an essencial commitment to the society they were part of. The struggle was able to add university students from the rest of the country, as well as from the Workers' Federation of Córdoba, an alliance that kept them linked in different moments of the century.

On June 21, 1918, the Manifesto that synthesized the urgency of a public, free, secular, co-governed university, with public competitions, periodicity in the exercise of teaching, autonomous, committed to the nation was released. In the following years the principles were supported by students from Chile, Peru, Cuba, Mexico, Paraguay and Brazil. That manifesto expresses a "We" that disputes a symbolic power in favor of the rebellion of the students in this "American hour" when "young people no longer ask but demand".

Today another manifesto comes back to join us in favor of education, freedom, educational research, the socio-political context in which we are involved A manifesto for Educa- tion published in 2010 by Gert Biesta and Carl Anders Säfström and, whose reading allows us to reflect and manifest about the meanings of education almost ten years after its publication.

To open this manifesto, they propose to speak in the name of education, recognizing attacks originated in populist and idealistic directions, but moving away from those looks. Speaking in the name of education expresses an interest in the freedom of "the others". In the same document, education is located in a tension between "what is" and "what is not". In this tension, a present-dissent breaks in, produces subjectivity and requires considering education as fundamentally historical and open to new things. This tension helps raise questions about forms to theorize education in an educational way.

“... the manifesto aims to identify the challenges that must be faced if we want to fight for education, which also means fighting for the possibility of freedom"

Gert Biesta wonders: "A manifesto for Education?" And he recognizes that just as in the domain of art and politics that have dominated in this genre, none of them has managed to change the world. For that reason he expresses "In our times a manifesto can only be done in an ironic way"; that is to say, to create an opening; to speak in the name of education; to discuss from that place the theoretical and political attacks; to build a theory of education 
that borrows from other academic disciplines; to ask if such theoretical resources can capture the educational dimension of education.

Carl Anders Säfström makes a brief historical introduction in order to provide a context for education in Sweden and the fundamental sense that education resides at the base of the modern welfare state, a 'social democratic' state. The attacks of the new right to this state imply attacks on education and educational research. In relation to the latter, it depends on the current public policies and it is easily reduced to the application of ideas from politics or from other disciplines (specific didactics, educational sociology, educational psychology, among others). This is not the education we want. It's time to fight for education!

This dossier that we present today is coordinated by PhDs. Luis Porta (UNMDP-CONICET-GIEEC) and Silvia Grinberg (CONICET - UNSAM- CEDESI). They analyze polyphon- ic manifestations of pedagogy from the eleven resistance exercises in favor of education that are published. A singular effort, that involves an ethical and political intentionality to inhabit, -from that place- a world that commits us for a better, freer and more respectful life.

It is a special volume, as it is organized in a dossier focused on the reflections generated from the Manifesto, it is also particular because all the articles and reviews are published in Spanish and in English and it has a greater amount of collaborations in this topic (European, Latin American and Argentinian).

As Gert Biesta and Carl Anders Säfström say, in the Manifesto there is no invitation to join to something but to begin to speak in the name of education, to multiply and not to copy. A territory to gather forces, to venture thinking, to revisit the school, the common, the research and -from that place- to resist by rethinking the different senses of education.

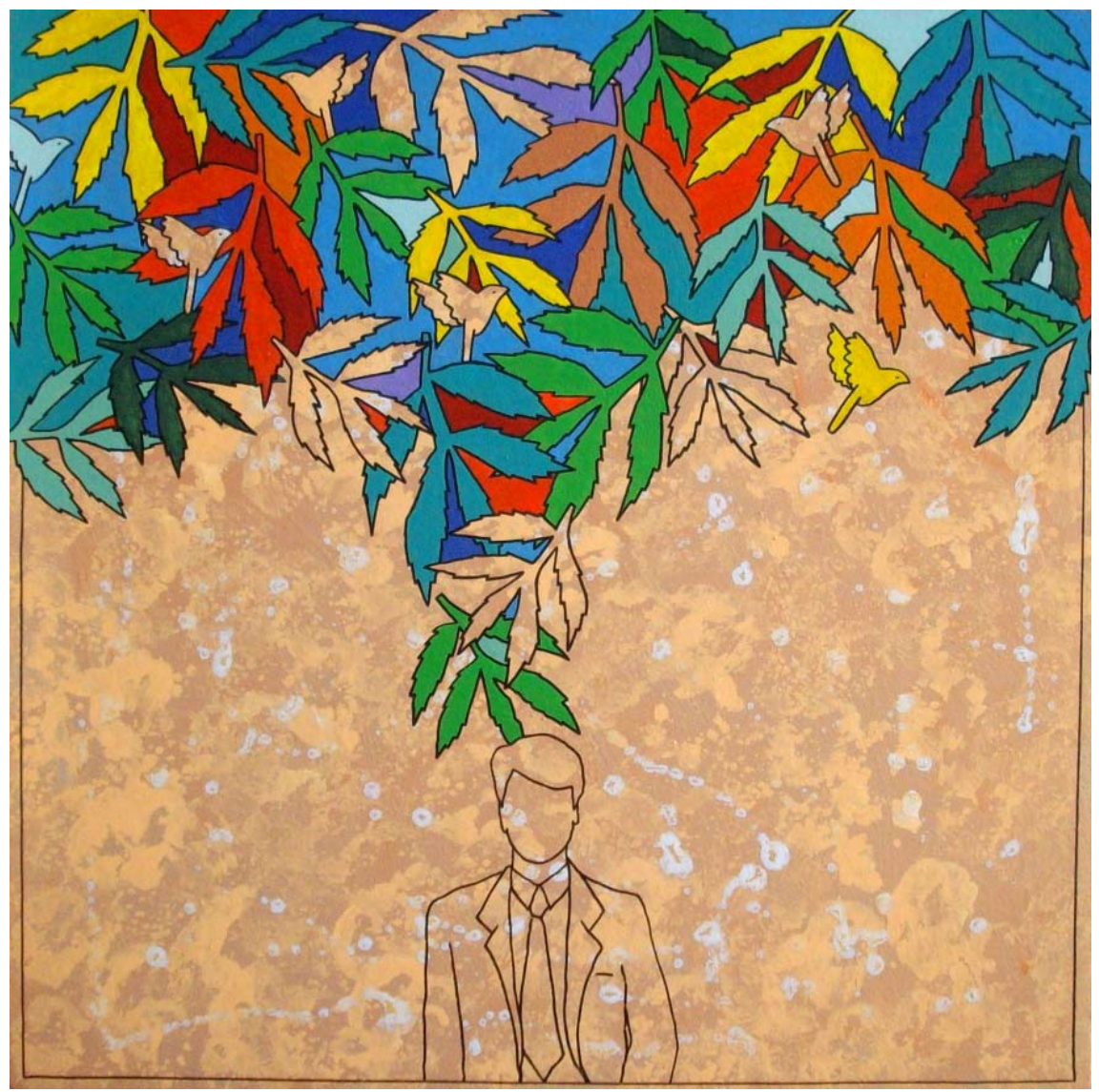

Indifferent series, mix technique. Luis Abraham 